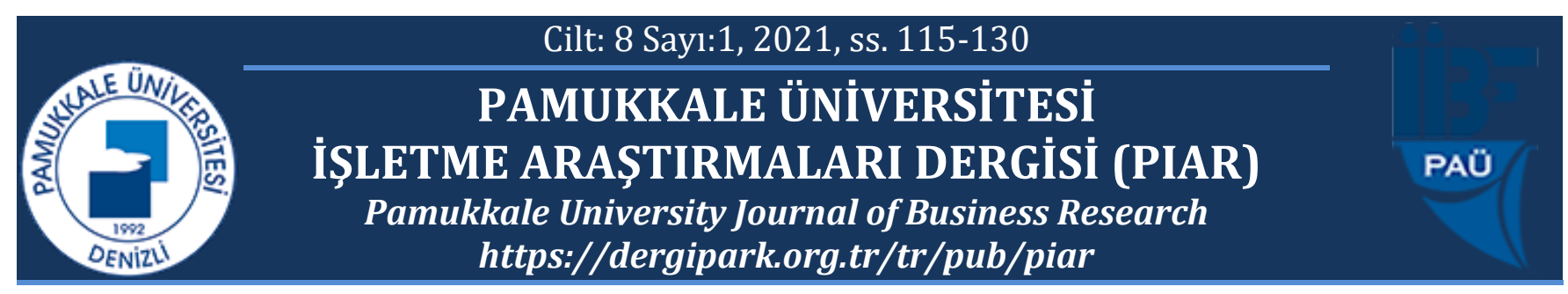

\title{
Mikro ve Küçük İşletmelerin Muhasebe Mesleğine Karşı Tutumlarının Tanımlayıcı Değişkenlere Göre Araştırılması: Isparta İli Örneği
}

\section{Research of Micro and Small Businesses' Attitudes Towards Accounting Profession According to Descriptive Variable: Isparta Example}

\section{İsmail BEKC $\dot{I}^{1} \quad$ Ali APALI ${ }^{*} \quad$ Elif ÖZER ${ }^{3}$}

1 Süleyman Demirel Üniversitesi, İktisadi ve İdari Bilimler Fakültesi, İşletme Bölümü, ismailbekci@sdu.edu.tr, https://orcid.org/0000-0002-9862-737X

${ }^{2}$ Mehmet Akif Ersoy Üniversitesi, Zeliha Tolunay Uygulamalı Teknoloji ve İşletmecilik Yüksekokulu, Muhasebe ve Finans Yönetimi Bölümü, aapali@mehmetakif.edu.tr, https://orcid.org/0000-0002-3521-0150

${ }^{3}$ Mehmet Akif Ersoy Üniversitesi, Sosyal Bilimler Enstitüsü, Muhasebe ve Finansman A.B.D., elifozer032@gmail.com, https://orcid.org/0000-0002-1693-1542

* Yazışılan Yazar/Corresponding author

Öz

Mikro ve küçük işletmeler, ülke ekonomisinde önemli bir yere sahiptir. Ekonomide istihdam să̆lama, büyümeyi artırma ve yatırım konularında büyük fayda sağlamaktadır. Mikro ve küçük işletmeler, ticari faaliyetlerinin yürütülmesinde muhasebe departmanı ile iç içedir. Bu nedenle araştırmanın konusunu mikro ve küçük işletmelerin muhasebe mesleğine karşı tutumları oluşturmaktadır. Bu konuda Isparta ilinde faaliyet gösteren mikro ve küçük işletmelerin muhasebe mesleğine karşı tutumlarının katılımcıların tanımlayıcı değişkenlerine göre farklılaştırılıp farklılaştırılmadı̆̆̆ııın araştırması amaçlanmıştır. Isparta ilinde faaliyet gösteren mikro ve küçük işletmelerden anket yöntemi ile veriler toplanmış ve elde edilen verilere güvenilirlik analizi, frekans ve yüzde dă̆ılımı analizi, uygulanmıştır. Araştırmanın konusuna ve amacına uygun olarak 8 hipotez oluşturulmuştur. Hipotezlere One Way Anova ve Independent-samples $T$ testi uygulanmiştır. Uygulanan analiz sonucunda ise 8 hipotezin 5'i reddedilmiş, 3'ü kabul edilmiştir.

Anahtar kelimeler: Isparta, Mikro ve Küçük Isşletmeler, Muhasebe Mesleği.

JEL kodlart: M40, M49

\begin{abstract}
Micro and small businesses have a significant place in the country's economy. They have great benefits in terms of providing employment, increasing growth and investment. It is intertwined with the accounting department in the conduction of transactions of micro and small enterprises. Therefore, the subject of the study is the attitudes of micro and small enterprises towards the accounting profession. In this respect, it is aimed to investigate whether the attitudes of micro and small enterprises operating in Isparta province towards the accounting profession are differentiating according to the descriptive variables of the participants. The data were collected from micro and small enterprises operating in Isparta province with a survey method and reliability analysis, frequency and percentage distribution analysis were applied to the obtained data. 8 hypotheses were formed in accordance with the subject and purpose of the research. One Way Anova and Independent-samples $T$ tests were applied to hypotheses. As a result of the analysis, 5 of the 8 hypotheses were rejected and 3 were accepted.
\end{abstract}

Keywords: Isparta, Micro and Small Businesses, Accounting Profession.

JEL codes: $M 40$, M49 


\section{GİRIŞ}

Mikro ve küçük işletmelerin Dünya ekonomisindeki yeri giderek artmakta ve önem kazanmaktadır. Bu işletmeler, ülke ekonomilerinin gelişimine katkı sağlaması bakımından da gelişmiş ve gelişmekte olan ülkelerin en önemli yapı taşlarını oluşturmaktadırlar. Bölgesel ve bölgelerarası dengesizliğin giderilmesinden, üretim kaynaklarının verimli olarak kullanılmasına kadar ekonominin vazgeçilmez unsurlarından biri olan mikro ve küçük işletmeler, ülkelerin ekonomi stratejilerinin oluşmasında da etkili olmaktadır. Mikro ve küçük işletmeler, tüm ülkelerde olduğu gibi Türkiye' de de istihdam oluşturma, girişimciliği artırma ve bölgesel olarak kalkınma aracı olarak önemli görevler üstlenmektedirler. Bu bağlamda mikro ve küçük işletmelerin ülke ekonomilerine sağladıkları katkılar her geçen gün artmaktadır. Küçük ve esnek olmaları bakımından mikro ve küçük işletmeler, diğer işletmelerden ayrılmaktadırlar. Bu özellikleri ile ülke ekonomilerine hareketlilik katarlar. Ülke ekonomisinin yanı sıra sosyal dengelerin ve kararların önemli bir kısmını oluşturmaktadırlar. Ekonominin temel yapı taşlarını oluşturmakla birlikte küçük olmaları ve yönetimde hızlı değişkenlik sağlaması ile piyasaya ve yeniliklere uyum sağlamada esnek bir yapıya sahiptirler.

Geçmiş işlemleri kaydedip yazılı bellek görevini yerine getirerek bilgi aracı rolü üstlenen, bütçe ve standartlarla fiili durumu karşılaştırıp sapmaları ortaya çıkararak kontrol fonksiyonu görevi gören ve üretilen bilgilerle geleceğe ait tahminlerde bulunmaya ve planlamaya yardımcı olan muhasebe ve muhasebe mesleği, işletmenin vereceği kararlarda yol gösterici nitelik taşıyan, ekonomik hayatta giderek artan öneme sahip olan bir meslektir. İşletme açısından muhasebenin ürettiği bilgilerin işletme yöneticilerinin kararlarından, çalışanların kararlarına kadar tüm bireyler için önemlidir. Dolayısıyla mikro ve küçük işletmelerin muhasebe ve muhasebe mesleğine karşı tutumlarının farklılık göstermesi beklenmektedir.

$\mathrm{Bu}$ araştırmada mikro ve küçük işletmelerin muhasebe mesleğine karşı tutumlarının tanımlayıcı değişkenlere göre araştırması amaçlanmıştır. Bu amaç doğrultusunda araştırma verileri Isparta ilindeki KOSGEB veri tabanına kayıtlı aktif 7.396 Isşletmeden 302 işletme temsilcisine yapılan anketlerden elde edilmiş olup, mikro ve küçük işletme temsilcilerinin muhasebe mesleğine karşı tutumları ortaya konulmaya çalışılmıştır.

\section{MUHASEBE MESLEĞ $\dot{I}$}

Muhasebe, işletme ile ilgili tüm kişi ve kuruluşlara ihtiyaç duydukları finansal nitelikli bilgileri üretip bu bilgileri raporlar aracılığıyla ilgililere sunarken aynı zamanda ekonomik, sosyal ve teknolojik alanlardaki gelişmelerin etkisiyle de ürettiği bilgilerin kapsamını genişletmekte ve niteliklerini değiştirmektedir (Akdoğan, 2003: 18). Bu değişimi ifade eden kişiler muhasebe meslek mensuplarıdır. Muhasebe meslek mensubu biçimsel eğitim ve uygulamada edindiği muhasebe bilgi, beceri ve deneyimlerini talep edenlere (muhasebe ve finansal işlemler konusunda) muhasebecilik mesleği ile ilgili yasalar ve mesleki kuruluşlarının göz önünde tuttuğu sınırlar içinde sunarak yaşamını devam ettiren bir profesyonel (Civelek ve Durukan, 1997: 3) olarak tanımlanmaktadır. Bu profesyonellik muhasebe mesleğini ortaya çıkarmıştır. Muhasebe mesleği, geçmişte çok uzun bir sürece dayanan, üslendiği fonksiyonlarla tarih boyunca ticaret hayatına yön veren, dolayısıyla sosyal hayata da etki eden ve yol gösteren, gerek işletme açısından, gerek toplum ve devlet açısından büyük önem taşıyan bir meslektir. Tarihi süreçte, ülkeden ülkeye farklılıklar gösteren muhasebe mesleği, 
son zamanlarda birbirlerine uyumlu hale getirilmiş ve böylece küresel ekonominin en önemli niteliklerden biri haline gelmiştir. Muhasebe meslek mensuplarının ve profesyonel muhasebe şirketlerinin, toplumdaki ve işletme dünyasındaki yerinin giderek arttığ görülmüştür (Özyürek, 2012: 139-140).

Muhasebe mesleği devlete, topluma, mesleki kuruluşlara ve kendisine karşı sorumlulukları ile yükümlü olan bir meslektir. Yaşamını devam ettirebilmesi için gerekli olan geliri kendisine sağlayan müşterilerinin çıkarlarını gözeterek onlara hizmet sunmak zorundadır (Civelek ve Durukan, 1997: 2).

Muhasebe mesleğinde, 1989 yılında çıkartılan 3568 sayılı "Serbest Muhasebeci, Serbest Muhasebeci Mali Müşavir ve Yeminli Mali Müşavirlik Kanunu" ile muhasebecilik mesleğinin kurumsallaşma sürecinde Türkiye'de Muhasebe mesleğinde yeni bir dönem açıldığ1 bilinmektedir. 26.07.2008 tarihinde 5786 Sayılı Kanunun düzenlemesiyle birlikte 1. maddede, kanunun amacı, "işletmelerde faaliyetlerin ve işlemlerin sağlıklı ve güvenilir bir şekilde işleyişini sağlamak, faaliyet sonuçlarını ilgili mevzuat çerçevesinde denetlemeye, değerlendirmeye tabi tutarak gerçek durumu ilgililerin ve resmi mercilerin istifadesine tarafsız bir şekilde sunmak ve yüksek mesleki standartları gerçekleştirmek üzere, "Serbest Muhasebeci Mali Müşavirlik" ve "Yeminli Mali Müşavirlik" meslekleri ve hizmetleri ile Serbest Muhasebeci Mali Müşavirler ve Yeminli Mali Müşavirler Odaları, Serbest Muhasebeci Mali Müşavirler ve Yeminli Mali Müşavirler Odaları Birliğinin kurulmasına, teşkilat, faaliyet ve denetimlerine, organlarının seçimlerine dair esasları düzenlemektir" şeklinde ifade edilmiştir (3568 Sayılı Serbest Muhasebeci Mali Müşavirlik ve Yeminli Mali Müşavirlik Kanunu, Erişim: 27.03.2020).

Son zamanlarda muhasebe mesleği basit bir şekilde defter tutmanın yanı sıra işletmenin vereceği kararlarda yol gösterici nitelik taşıyan bir meslek haline gelmiştir İşletmelerin ve yöneticilerin işletmede meydana gelen değişikleri, işletmenin mevcut durumlarını ve gelecekteki durumlarını incelemeleri gerekmektedir. Bu amaca ulaşabilmek için yöneticilerin bilgileri doğru kaynaktan almaları gerekmektedir ve muhasebenin sağladığı bilgiler ile işletmenin alacağı kararlarda muhasebeciler yol gösterici olmaktadır (Demir ve Tanyıldızı, 2017: 194).

\section{MİKRO ve KÜÇÜK İŞLETMELERDE KAVRAMSAL ÇERÇEVE}

KOBİ, yıllık iki yüz elli kişiden az çalışan istihdam eden ve yıllık net satış hasılatı veya mali bilançosundan herhangi biri yüz yirmi beş milyon Türk lirasını aşmayan işletmelere, mikro işletme, küçük işletme ve orta büyüklükteki işletme olarak sınıflandıran ekonomik birimleri veya girişimleri ifade eder (https://www.kosgeb.gov.tr, Erişim: 03.03.2020). Türkiye'deki işletmelerin \%99,82'sini küçük ve orta büyüklükteki işletmeler oluşturmakta ve bu işletmeler toplam istihdamın \%76,7'sini sağlamaktadır. Bu oranlar, ülke ekonomisinde KOBİ'lerin yeri ve öneminin büyüklüğünü genel olarak ifade göstermektedir (https://www.mfa.gov.tr, Erişim: 04.03.2020). Bu veriler de göstermektedir ki mikro ve küçük işletmeler, tüm işletmeler içerisinde oldukça yüksek bir paya sahiplerdir. Türkiye'de mikro ve küçük işletmelerin sınıflandırılması aşağıdaki Tablo 1'de görüleceği gibidir. 
Tablo 1. Türkiye'de Mikro ve Küçük İşletmelerin Sınıflandırılması

\begin{tabular}{|c|c|c|c|}
\hline & Net Satış Hasılatı (TL) & Mali Bilanço Değeri (TL) & Çalışan Sayısı \\
\hline Mikro İşletme & $<3.000 .000$ & $<3.000 .000$ & $<10$ \\
\hline Küçük İşletme & $<25.000 .000$ & $<25.000 .000$ & $<50$ \\
\hline
\end{tabular}

Kaynak: https://www.kosgeb.gov.tr/Küçük ve Orta Büyüklükteki İşletmelerin Tanımı, Nitelikleri ve Sınıflandırılması Hakkında Yönetmelik, Erişim: 03.03.2020.

Küçük ve orta büyüklükteki işletmelerin tanımı, nitelikleri ve sinıflandırılması hakkında yönetmelikte yayınlanan ve madde 5 'te yer alan mikro ve küçük işletmeler aşağıdaki şekilde sinıflandırılmıştır (https://www.kosgeb.gov.tr/Küçük ve orta büyüklükteki işletmelerin tanımı, nitelikleri ve sınıflandırılması hakkında yönetmelik, madde 5). Mikro işletme, on kişiden az yıllık çalışan istihdam eden ve yıllık net satış hasılatı veya mali bilançosundan herhangi biri üç milyon Türk Lirasını aşmayan işletmeler olarak belirlenmiş iken, küçük işletme ise, elli kişiden az yıllık çalışan istihdam eden ve yıllık net satış hasılatı veya mali bilançosundan herhangi biri yirmi beş milyon Türk Lirasını aşmayan işletmeler (https://www.kosgeb.gov.tr, Erişim: 03.03.2020) olarak tanımlanmış ve sınıflandırılmış ve bu sınıflandırma araştırmada mikro ve küçük işletme ayrımında esas alınmıştır.

\section{LİTERATÜR ÖZETI}

Muhasebe mesleğine bakış açısına yönelik, Isparta ilinde faaliyet gösteren mikro ve küçük işletmelerin muhasebe mesleğine bakış açılarını ortaya koyan nitelikte birebir araştırma tespit edilememiştir. Konu ile ilgili ve benzer araştırmaları ise aşağıdaki gibi sıralamak mümkündür.

Bekçi ve Usul (2001), Göller bölgesindeki küçük ve orta büyüklükteki işletmelerin finansal sorunları ve çözüm önerilerine yönelik bir çalışma yapmışlardır. Çalışmada bölgede faaliyet gösteren Kobilerin en büyük sorununun yetersiz finansman yapısı olduğu görülmektedir. Bu nedenle diş kredi faizlerinin yüksek olmasının yanında KOBİlerin finansal teknikleri kullanmamaları sonucuna ulaşılmıştır.

Ekşi vd. (2011), araştırmalarında muhasebe meslek mensubu olmaya aday öğrencilerin, muhasebe mesleğine bakış açılarına dair araştırma yapmışlardır. Analiz sonucuna göre cinsiyet farklılı̆̆ının muhasebe mesleğinin idrak edilmesinde önemli olmadığı belirtilmiştir. Kullanılan ikinci değişkende ise öğrenim düzeyi farklılıklarının cinsiyet değişkeninin tersine algılama farklılıklarına sebep olduğu sonucuna ulaşılmıştır.

Albez ve Bilici (2012), Erzurum Atatürk Üniversitesi meslek yüksekokullarındaki muhasebe ve vergi uygulamaları bölümü öğrencilerinin muhasebe mesleğine bakış açılarını belirlemeye yönelik araştırma yapmışlardır. Araştırmanın sonucunda, öğrencilerin \%66 oranında büyük bir kısmının meslek elemanı olmak istedikleri ve bu öğrencilerin de \%60'ının lisans eğitimini tamamladıktan sonra muhasebe meslek elemanı olmak istedikleri tespit edilmiştir.

Tepeli ve Kayıhan (2015), Muğla Sıtkı Koçman Üniversitesi işletme bölümü öğrencilerinin muhasebe mesleğine bakış açlarını tespit etmeye yönelik bir araştırma yapmışlardır. Araştırma sonucunda işletme öğrencilerinin muhasebe mesleğine yönelmelerinde etki gösteren dersler ve faktörler, öğrencilerin demografik özelliklerine göre değerlendirmeler gerçekleştirilmiş ve mesleğe yönelmeye etki etmesinde farklılık gösterdiği sonucuna varılmıştır. 
Erduru vd. (2017), Ömer Halis Demir Üniversitesi Sosyal Bilimler Meslek Yüksekokulu Muhasebe ve Vergi Uygulamaları bölümünde öğrenim gören öğrencilerin, muhasebe mesleğini tercih etme sebeplerinden ortaya çıkan mesleğe bakış açıları ve bu bakış açılarının demografik etkenlere göre farklılaşıp farklılaşmadığının tespitine yönelik bir araştırma yapmışlardır. Öğrencilerin muhasebe mesleğine bakış açıları ve muhasebe mesleğini tercih etme fikirlerinin demografik etkenlere göre farklılaşıp farklılaşmadığı analizinin yapılması sonucunda cinsiyetlerine göre farklılık gözetmediği ortaya çıkmıştır.

Yürekli (2017), Pamukkale Üniversitesi Honaz Meslek Yüksekokulu Öğrencilerinin muhasebe eğitimine ve muhasebe mesleğine bakış açılarını araştırmaya yönelik bir araştırma yapmıştır. Araştırmada öğrencilerin beklentilerinin önemli bir kısmını muhasebe belge düzeni ve alandaki mesleki uygulamalarının ders saatinin artırımının yapılması, Türk Ticaret Kanunu ile Vergi Usul Kanunun dersin içeriğinde geniş bir şekilde anlatım sağlanması yönünde fikir bildirdikleri sonucuna varılmıştır.

Aksoylu vd. (2018), Erciyes Üniversitesi Uygulamalı Bilimler Yüksekokulu Muhasebe ve Finans Yönetimi bölümü öğrencilerin muhasebe mesleğine bakış açısına ve mesleğe yönelme tutumlarını ortaya çıkarmak için araştırma yapmışlardır. Yapılan analizler sonucunda öğrencilerin büyük çoğunluğunun (\%81.5 oranında) mesleği tercih etmeleri konusunda istekli olduklarını ve mesleğe bakış açılarının bu konuda yeterince aktif bir rol üstlendiği sonucunu ortaya çıkardığı görülmüştür.

Literatür incelendiğinde, mikro ve küçük işletmelerin (temsilcilerinin) muhasebe mesleğine bakış açılarının tanımlayıcı değişkenler özelinde araştırıldığ edilememiştir. Bu nedenle Isparta ili özelinde araştırma gerçekleştirilmiştir.

\section{ARAŞTIRMA}

Bu bölümde araştırmanın konusu ve amacı, evreni ve örneklemi, sınırları, yöntemi ve araştırmanın hipotezlerine ait bilgiler yer almaktadır.

\subsection{Araştırmanın Konusu ve Amacı}

Mikro ve küçük işletmelere yönelik yapılan araştırmada işletme temsilcilerinin muhasebe mesleği hakkında görüşlerinin belirlenmesi, araştırmanın konusunu oluşturmaktadır. Araştırmanın amacı ise, Isparta ilinde faaliyet gösteren ve KOSGEB veri tabanına kayıtlı mikro ve küçük işletmelerin muhasebe mesleğine karşı tutumlarının tanımlayıcı değişkenlere göre istatistiksel açıdan farklılıklarının olup olmadığının tespit edilmesidir.

\subsection{Araştırmanın Evreni ve Örneklemi}

Isparta ilinde faaliyet gösteren ve KOSGEB veri tabanına kayıtlı aktif durumda olan KOBİ sayısı 7.396'dır. Bu sayı içerisinde ne kadarının mikro ve küçük işletme olduğu tespit edilememiştir. Ancak bu araştırmanın evreni, Isparta ilindeki mikro ve küçük işletmeler olduğu için anket uygulaması sadece mikro ve küçük işletmeler tespit edilerek uygulanmıştır. Pandeminin engelleyici faktörü dikkate alınarak anket uygulaması için 396 işletme ziyaret edilmiş olmasına rağmen bazı işletme temsilcileri anketi cevaplamak istemedikleri için bu evren dâhilinde mikro ve küçük işletmelerde faaliyet gösteren işletmelerden örneklem olarak 302 işletme temsilcisine anket yapılmıştır. Analize dahil edilen 302 mikro ve küçük işletme 
sayısının, pandemi koşullarında tam sayısının tespitindeki zorluklar nedeni ile evreni temsil ettiği varsayımı ile çalışma tamamlanmıştır.

Anketler Mehmet Akif Ersoy Üniversitesi 06.01.2021-42 tarih ve sayılı kararı etik kurul izin belgesi doğrultusunda uygulanmıştır. Mikro ve küçük işletmelerin muhasebe mesleğine karşı tutumları tespit edilerek belirlenen değişkenlere göre farklılıklar varsa tespit edilmeye çalışılmaktadır.

\subsection{Araştırmanın Sınırları}

Isparta ilinde faaliyet gösteren ve KOSGEB veri tabanına kayıtlı aktif durumda olan mikro ve küçük işletmeler araştırmanın konu bakımından sınırlandırılmasını oluşturmaktadır. 2021 Ocak ve Şubat aylarında veriler toplandığı için bu aylar araştırmanın zaman sınırlaması olarak belirlenmiştir. Araştırmanın Isparta ilinde faaliyet gösteren işletmelere uygulanması mekân bakımından sınırını oluşturmuştur.

\subsection{Araştırmanın Yöntemi}

Araştırmanın verileri mikro ve küçük işletmelerin temsilcileriyle yüz yüze görüşülerek anket yöntemi ile elde edilmiştir. Anket hazırlanırken, Aydın (2018), Erduru, Deran ve Çelik (2017), Tepeli ve Kayıhan (2015) araştırmalarından faydalanılmak için gerekli izinler alınarak ölçeklerinden bu araştırmada faydalanılmıştır. Araştırmada kullanılan anket formu iki bölümden oluşmaktadır. Birinci bölüm 11 tanımlayıcı sorudan oluşmakta, ikinci bölüm ise 5'li likert ölçeğine göre hazırlanmış olup muhasebe mesleği ile ilgili ifadeleri ve mikro ve küçük işletmelerin muhasebe mesleğine karşı tutumlarını tespit etmeye yönelik 15 ifadeden oluşmaktadır. Araştırma ifadelerinden elde edilen verilere SPSS 20.0 paket programı ile güvenilirlik analizi uygulanmıştır. Tanımlayıcı değişkenler ise frekans ve yüzde dağılımı, Independent-Samples T Testi ve One Way Anova testi analizlerine tabi tutulmuştur.

\subsection{Araştırmanın Hipotezleri}

1. Araştırmanın konusu ve amacı doğrultusunda mikro ve küçük işletmelerin muhasebe mesleğine bakış açısının tanımlayıcı değişkenlere göre araştırmasına yönelik olarak hazırlanan hipotezler şu şekildedir;

H1: "Mikro ve küçük işletmelerin muhasebe mesleğine bakış açllarının cinsiyet değişkenine göre farklılaşması istatistiksel olarak anlamlıdır".

$\mathbf{H}_{2}$ : "Mikro ve küçük işletmelerin muhasebe mesleğine bakış açılarının işletmedeki pozisyonu değişkenine göre farklılaşması istatistiksel olarak anlamlıdır".

$\mathbf{H}_{3}$ : "Mikro ve küçük işletmelerin muhasebe mesleğine bakış açılarının eğitim durumu değişkenine göre farklılaşması istatistiksel olarak anlamlıdır".

$\mathbf{H}_{4}$ : "Mikro ve küçük işletmelerin muhasebe mesleğine bakış açılarının işletmenin hukuki yapısı değişkenine göre farklılaşması istatistiksel olarak anlamlıdır".

H5: "Mikro ve küçük işletmelerin muhasebe mesleğine bakış açllarının işletmedeki çalışan sayısı değişkenine göre farklılaşması istatistiksel olarak anlamlıdır".

H6: "Mikro ve küçük işletmelerin muhasebe mesleğine bakış açılarının işletmenizin faaliyette bulunduğu sektör değişkenine göre farklılaşması istatistiksel olarak anlamlıdır". 


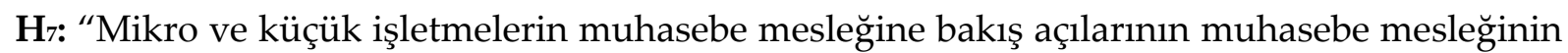
yararlı bulunması değişkenine göre farklılaşması istatistiksel olarak anlamlıdır".

H8: "Mikro ve küçük işletmelerin muhasebe mesleğine bakış açılarının muhasebenin ürettiği bilgileri işletmeler açısından faydalı bulunması değişkenine göre farklılaşması istatistiksel olarak anlamlıdır".

$\mathrm{Bu}$ hipotezler çerçevesinde araştırma verilerinin analiz sonuçları bir sonraki başlıkta araştırılmıştır.

\section{ARAŞTIRMANIN BULGULARI}

Bu başlık altında araştırmanın güvenilirlik analizinin yanı sıra hem tanımlayıcı sorularının frekans ve yüzde dağılımları hem de hipotez testleri gerçekleştirilmiştir.

\subsection{Güvenilirlik Analizi}

Araştırmanın amacına ve konusuna uygun bir şekilde hazırlanan anket sorularının güvenilirlik analizi sonuçları aşağıdaki tablo 2'de verilmiştir.

Tablo 2. Güvenirlik Analizi Sonuçları

\begin{tabular}{|c|c|}
\hline Cronbach's Alpha & N of Items \\
\hline 0,799 & 15 \\
\hline
\end{tabular}

Mikro ve küçük işletmelerin muhasebe mesleğine bakış açısını ölçmeye yönelik, araştırmanın ikinci kısmında yer alan ifadelere uygulanan güvenilirlik analizi sonucunda Cronbach's Alpha değeri 0,799 olarak bulunmuştur. Bu değer Kalaycı (2009:405)’ya göre 0,60< $<<0,80$ aralığında olduğu için ölçek “Oldukça Güvenilir” olarak kabul edilmektedir.

\subsection{Araştırmanın Tanımlayıcı Sorularının Frekans ve Yüzde Analizleri}

Araştırmaya dahil olan katılımcıların tanımlayıcı ifadelerinin cinsiyet, işletmedeki pozisyon, eğitim durumu, işletmenin hukuki yapısı, işletmedeki çalışan sayısı, işletmenin faaliyette bulunduğu sektör, muhasebe mesleğini yararlı bulmaları, muhasebe mesleğinin işletmelere faydası olması, işletmenin muhasebe işlemleri nerede yürütülmekte olduğu, muhasebenin ürettiği bilgileri işletme açısından faydalı buluyor musunuz? ifadesi ve en iyi muhasebeci mükellefine en az vergi ödeten muhasebeci mi? gibi ifadelerin yüzde ve frekans dağılımları gösterilmiştir. 
Tablo 3. Katılımcıların Tanımlayıcı Değişkenlerinin Yüzde ve Frekans Dağılımları

\begin{tabular}{|c|l|c|c|}
\hline Değişken & Kategori & Frekans & Yüzde (\%) \\
\hline \multirow{4}{*}{ Cinsiyet } & Kadın & 135 & 44,7 \\
\cline { 2 - 4 } & Erkek & 167 & 55,3 \\
\cline { 2 - 4 } & Toplam & $\mathbf{3 0 2}$ & $\mathbf{1 0 0 , 0}$ \\
\hline \multirow{5}{*}{ İşletmedeki Pozisyonunuz } & Müdür & 77 & 25,5 \\
\cline { 2 - 4 } & Müdür Yardımcisı & 28 & 9,3 \\
\cline { 2 - 4 } & Muhasebe Personeli & 26 & 8,6 \\
\cline { 2 - 4 } & İşletme Sahibi/Yönetici & 171 & 56,6 \\
\cline { 2 - 4 } & Toplam & $\mathbf{3 0 2}$ & $\mathbf{1 0 0 , 0}$ \\
\hline \multirow{4}{*}{ Eğitim Durumunuz? } & Lise & 162 & 53,6 \\
\cline { 2 - 4 } & Ön Lisans & 65 & 21,5 \\
\cline { 2 - 4 } & Lisans/ Lisansüstü & 75 & 24,8 \\
\cline { 2 - 4 } & Toplam & $\mathbf{3 0 2}$ & $\mathbf{1 0 0 , 0}$ \\
\hline
\end{tabular}

Tablo 3'de görüleceği gibi anket uygulamasına katılan toplam 302 katılımcıdan 135'ini (\%44,7) kadın, 167 'sini $(\% 55,3)$ erkek katılımcılar oluşturmaktadır. Analiz sonucunda elde edilen verilere göre erkek katılımcıların kadın katılımcılara göre \%10,6'lık bir farkla çoğunlukta olduğu görülmektedir.

Tablo 4. Katılımcıların İşletmeleri İle İlgili Tanımlayıcı Değişkenlerin Yüzde ve Frekans Dağılımları

\begin{tabular}{|c|l|c|c|}
\hline Değişken & Kategori & Frekans & Yüzde (\%) \\
\hline \multirow{3}{*}{ İşletmedeki Çalışan Sayınız? } & Mikro İşletme (1-9 kişi) & 239 & 79,1 \\
\cline { 2 - 4 } & Küçük İşletme (10-49 kişi) & 63 & 20,9 \\
\cline { 2 - 4 } & Toplam & $\mathbf{3 0 2}$ & $\mathbf{1 0 0 , 0}$ \\
\hline \multirow{4}{*}{ İşletmenizin Faaliyette Bulunduğu Sektörr? } & Gida & 55 & 18,2 \\
\cline { 2 - 4 } & Hizmet & 85 & 28,1 \\
\cline { 2 - 4 } & Otomotiv ve Metal & 20 & 6,6 \\
\cline { 2 - 4 } & Tekstil & 142 & 47,0 \\
\cline { 2 - 4 } & Toplam & $\mathbf{3 0 2}$ & $\mathbf{1 0 0 , 0}$ \\
\hline \multirow{3}{*}{ Hukuki Yapınız? } & ŞahıS Şirketleri & 182 & 60,3 \\
\cline { 2 - 4 } & Sermaye Şirketleri & 120 & 39,7 \\
\cline { 2 - 4 } & Toplam & $\mathbf{3 0 2}$ & $\mathbf{1 0 0 , 0}$ \\
\hline
\end{tabular}

Tablo 4'de katılımcıların İşletmedeki çalışan sayısı değişkenine göre; 239'u (\%79,1) Mikro işletme (1-9 kişi), 63'ü (\%20,9) Küçük işletme (10-49 kişi) olduğu görülmektedir. Elde edilen verilere göre 239'u (\%79,1) Mikro İşletme (1-9 kişi) aralığı çoğunluk göstermektedir. İşletmenin faaliyette bulunduğu sektör değişkenine göre; 55'ini (\%18,2) G1da, 85'i (\%28,1) Hizmet, 20'si $(\% 6,6)$ Otomotiv ve Metal, 142'si $(\% 47,0)$ Tekstil sektörleri oluşturmuştur. Ankete katılan katılımcların işletme içerisindeki pozisyonunu 77'si (\%25,5) Müdür, 28'i $(\% 9,3)$ Müdür Yardımcısı, 26'sı (\%8,6) Muhasebe Personeli ve 171'i (\%56,6) İşletme Sahibi/Çalışanları oluşturmaktadır. Ankete katılan katılımcıların eğitim durumlarına bakıldığında 162'sini $(\% 53,6)$ Lise, 65'ini (\%21,5) Ön Lisans, 75'ini (\%24,8) Lisans/Lisansüstü katılımcılar oluşturmaktadır. İşletmelerin hukuki yapılarının 182'si (\%60,3) şahıs şirketleri, 120'sini $(\% 39,7)$ Sermaye Şirketleri oluşturmaktadır. 
Tablo 5. Katılımcıların Muhasebe ve Muhasebe Mesleğine Yönelik Yüzde ve Frekans Dağılımları

\begin{tabular}{|c|c|c|c|}
\hline Değişken & Kategori & \begin{tabular}{c|c}
$\begin{array}{c}\text { Freka } \\
\text { ns }\end{array}$ \\
\end{tabular} & $\begin{array}{c}\text { Yüzde } \\
(\%)\end{array}$ \\
\hline \multirow[t]{4}{*}{$\begin{array}{c}\text { İşletmenizin Muhasebe İşlemleri Nerede } \\
\text { Yürütülmektedir? }\end{array}$} & $\begin{array}{l}\text { Tamamen Bağımsız Bir } \\
\text { Muhasebe Bürosunda }\end{array}$ & 196 & 64,9 \\
\hline & $\begin{array}{l}\text { İşletmede Kismen } \text { Muhasebe } \\
\text { Bürosunda }\end{array}$ & 62 & 20,5 \\
\hline & Tamamen İşletmemizde & 44 & 14,6 \\
\hline & Toplam & 302 & 100,0 \\
\hline \multirow{4}{*}{$\begin{array}{l}\text { Muhasebenin Ürettiği Bilgileri İşletmeniz Açısında } \\
\text { Faydalı Buluyor Musunuz? }\end{array}$} & Evet & 241 & 79,8 \\
\hline & Hayır & 13 & 4,3 \\
\hline & Kismen & 48 & 15,9 \\
\hline & Toplam & 302 & 100,0 \\
\hline \multirow{4}{*}{$\begin{array}{c}\text { En İyi Muhasebeci Mükellefine En Az Vergi Ödeten } \\
\text { Muhasebeci Midir? }\end{array}$} & Evet & 85 & 28,1 \\
\hline & Hayır & 126 & 41,7 \\
\hline & Kismen & 91 & 30,1 \\
\hline & Toplam & 302 & 100,0 \\
\hline \multirow{3}{*}{ Muhasebe Mesleğini Yararlı Buluyor Musunuz? } & Evet & 293 & 97,0 \\
\hline & Hayır & 9 & 3,0 \\
\hline & Toplam & 302 & 100,0 \\
\hline \multirow{4}{*}{$\begin{array}{l}\text { Muhasebe Mesleğinin İşletmelere Faydası Olduğunu } \\
\text { Düşünüyor Musunuz? }\end{array}$} & Evet & 264 & 87,4 \\
\hline & Hayır & 8 & 2,6 \\
\hline & Kismen & 30 & 9,9 \\
\hline & Toplam & 302 & 100,0 \\
\hline
\end{tabular}

Tablo 5'te İşletmenizin muhasebe işlemleri nerede yürütülmektedir? sorusuna 196'sı $(\% 64,9)$ tamamen bağımsız bir muhasebe bürosunda, 62'si (\%20,5) işletmede k1smen muhasebe bürosunda, 44 'ü $(\% 14,6)$ tamamen işletmemizde olarak değişkenlik göstermiştir. Muhasebenin ürettiği bilgileri işletmeniz açısından faydalı buluyor musunuz? sorusuna 241'i $(\% 79,8)$ "Evet", 13'ü $(\% 4,3)$ "Hayır", 48 'ini $(\% 15,9)$ "Kısmen" olarak cevaplar saptanmıştır. En iyi muhasebeci mükellefine en az vergi ödeten muhasebeci midir? sorusuna 85'i (\%28,1) "Evet", 126'sı (\%41,7) "Hayır", 91'i (\%30,1) "Kısmen" cevabı olarak saptanmıştır. Ankete katılan katılımcların muhasebe mesleğini yararlı buluyor musunuz? sorusuna 293'ü (\%97) "Evet", 9'u (\%3) "Hayır" yanıtını vermişlerdir. Elde edilen verilere göre \%95,0 farkla muhasebe mesleğini yararlı buldukları saptanmıştır. Ankete katılan katılımcıların muhasebe mesleğinin işletmelere faydası olduğunu düşünüyor musunuz? sorusuna 264'ü $(\% 87,4)$ "Evet", 8'i $(\% 2,6)$ "Hayır", 30'u (\%9,9) "Kısmen" olarak cevaplar vermişlerdir.

Tablo 6'da mikro ve küçük işletmelerin cinsiyet değişkenine göre Independent-Samples T Testi sonuçları gösterilmiştir.

Tablo 6. Mikro ve Küçük İşletme Katılımcılarının Cinsiyet Değişkenine Göre IndependentSamples T Testi Sonuçları

\begin{tabular}{|c|c|c|c|c|c|c|}
\hline \multicolumn{2}{|c|}{ Değişken } & N & Ortalama & Standart Sapma & t & p \\
\multirow{2}{*}{ Cinsiyet } & Kadın & 135 & 4,1333 & 0,89609 & \multirow{2}{*}{0,920} & \multirow{2}{*}{0,444} \\
\cline { 2 - 6 } & Erkek & 167 & 4,2096 & 0,82748 & & \\
\hline
\end{tabular}


Yapılan analizler sonucunda p değeri 0,444>0,05 olduğu için $\mathrm{H}_{1}$ hipotezi olan “Mikro ve küçük işletmelerin muhasebe mesleğine bakış açlarının cinsiyet değişkenine göre farklılaşması istatistiksel olarak anlamlıdır" ifadesi reddedilmiştir. Dolayısıyla mikro ve küçük işletme katılımcılarının muhasebe mesleğine karşı tutumları cinsiyet değişkenine göre farklılık göstermemektedir. Yani gruplar arasında oluşan farklılık istatistiksel açıdan anlamlı değildir.

Tablo 7'de mikro ve küçük işletme katılımcılarının işletmedeki pozisyonu değişkenine göre One Way Anova testi sonuçları gösterilmiştir.

Tablo 7. Mikro ve Küçük İşletme Katılımcılarının İşletmedeki Posizyonu Değişkenine Göre One Way Anova Testi Sonuçları

\begin{tabular}{|c|l|c|c|c|c|c|c|c|}
\hline \multicolumn{2}{|c|}{ Değişken } & N & Mean & $\begin{array}{c}\text { Standart } \\
\text { Sapma }\end{array}$ & $\begin{array}{c}\text { Kareler } \\
\text { Toplamı }\end{array}$ & $\begin{array}{c}\text { Kareler } \\
\text { Ortalaması }\end{array}$ & F & P \\
\hline \multirow{4}{*}{$\begin{array}{c}\text { İşletmedeki } \\
\text { Pozisyonu }\end{array}$} & Müdür & 77 & 4,1818 & 0,77336 & & & & \\
\cline { 2 - 6 } & $\begin{array}{l}\text { Müdür } \\
\text { Yardımcisı }\end{array}$ & 28 & 4,5357 & 0,69293 & & & \\
\cline { 2 - 5 } & $\begin{array}{l}\text { Muhasebe } \\
\text { Personeli }\end{array}$ & 26 & 4,3846 & 0,63730 & 6,272 & 2,091 & 2,892 & 0,036 \\
\cline { 2 - 5 } & $\begin{array}{l}\text { İsletme } \\
\text { Sahibi/Yönetici }\end{array}$ & 171 & 4,1755 & 0,92943 & & & & \\
\hline
\end{tabular}

Yapılan analiz sonucunda $p$ değeri 0,036<0,05 olduğu için $\mathrm{H}_{2}$ hipotezi olan "Mikro ve küçük işletmelerin muhasebe mesleğine bakış açılarının işletmedeki pozisyonu değişkenine göre farklılaşması istatistiksel olarak anlamlıdır" ifadesi kabul edilmiştir. Yani gruplar arasında oluşan farklılık istatistiksel açıdan anlamlıdır. Bu farklılığın hangi gruplar arasında olduğunu tespit etmek için Post Hoc testlerinin sonuçlarının incelenmesi gerekmektedir. Kayri (2009), hangi post hoc testini kullanılacağının gruplar arasındaki varyansların eşit olup olmaması ve örneklem büyüklüğünün eşit olup olmamasına göre karar verilmesi gerektiğini ifade etmiştir. Buna göre bu araştırmanın gruplar arasındaki varyansları homojen dağılım göstermiş ( $P=0,974>0,05$ olduğu için) ve örneklem büyüklüğü de eşit dağılmamıştır. Bu şartlar doğrultusunda tercih edilecek testlerden en çok tercih edileni Bonferroni testidir (Kayri, 2009: 56). Post Hoc testlerinden Benferroni'nin sonuçları Tablo 8' de gösterilmektedir.

Tablo 8. H2 Post Hoc Testi

\begin{tabular}{|c|c|c|c|c|}
\hline \multirow{13}{*}{$\begin{array}{l}\text { İşletmedeki } \\
\text { Pozisyonu }\end{array}$} & \multicolumn{2}{|c|}{ Varyans Kaynağı } & Ortalamaların Farkı & $\mathbf{P}$ \\
\hline & \multirow{3}{*}{ Genel Müdür } & Genel Müdür Yardımcısı & 0,35390 & 0,362 \\
\hline & & Muhasebe Personeli & $-0,20280$ & 1,000 \\
\hline & & İşletme Sahibi/Çalışan & 0,09995 & 1,000 \\
\hline & \multirow{3}{*}{ Genel Müdür Yardımcısı } & Genel Müdür & 0,35390 & 0,362 \\
\hline & & Muhasebe Personeli & 0,15110 & 1,000 \\
\hline & & İşletme Sahibi/Çalışan & 0,45384 & 0,056 \\
\hline & \multirow{3}{*}{ Muhasebe Personeli } & Genel Müdür & 0,20280 & 1,000 \\
\hline & & Genel Müdür Yardımcısı & $-0,15110$ & 1,000 \\
\hline & & İşletme Sahibi/Çalışan & 0,30274 & 0,551 \\
\hline & \multirow{3}{*}{ İşletme Sahibi/Yönetici } & Genel Müdür & $-0,09995$ & 1,000 \\
\hline & & Genel Müdür Yardımcısı & $-0,45384$ & 0,056 \\
\hline & & Muhasebe Personeli & $-0,30274$ & 0,551 \\
\hline
\end{tabular}


Analiz sonucuna göre modelde bir bütün olarak gruplar arasında bir farklılık ortaya çıkmasına rağmen ikili testler sonucunda gruplar arasında fark ortaya çıkmamıştır. Yani ikili gruplarda fark anlamlı değildir.

Tablo 9'da mikro ve küçük işletme katılımcılarının eğitim durumu değişkenine göre One Way Anova testi sonuçları gösterilmiştir.

Tablo 9. Mikro ve Küçük İşletme Katılımcılarının Eğitim Durumu Değişkenine Göre One Way Anova Testi Sonuçları

\begin{tabular}{|c|c|c|c|c|c|c|c|c|}
\hline \multicolumn{2}{|c|}{ Değişken } & N & Mean & $\begin{array}{c}\text { Standart } \\
\text { Sapma }\end{array}$ & $\begin{array}{c}\text { Kareler } \\
\text { Toplami }\end{array}$ & $\begin{array}{c}\text { Kareler } \\
\text { Ortalaması }\end{array}$ & F & P \\
\hline \multirow{2}{*}{$\begin{array}{c}\text { Eğitim } \\
\text { Durumu }\end{array}$} & Lise & 162 & 4,1420 & 0,94486 & & & & \multirow{2}{*}{0} \\
\cline { 2 - 5 } & Ön Lisans & 65 & 4,2000 & 0,73314 & 0,417 & 0,209 & 0,282 & 0,754 \\
\cline { 2 - 9 } & Lisans/Lisansüstü & 75 & 4,2267 & 0,76359 & & & \\
\hline
\end{tabular}

Yapılan analiz sonucunda $\mathrm{p}$ değeri 0,754>0,05 olduğu için $\mathrm{H}_{3}$ hipotezi olan “Mikro ve küçük işletmelerin muhasebe mesleğine bakış açılarının eğitim durumu değişkenine göre farklılaşması istatistiksel olarak anlamlıdır" ifadesi red edilmiştir. Dolayısıyla mikro ve küçük işletmelerin muhasebe mesleğine karşı tutumları işletmenin eğitim durumu değişkenine göre farklılık göstermemektedir. Yani gruplar arasında oluşan farklılık istatistiksel açıdan anlamlı değildir.

Tablo 10'da mikro ve küçük işletme katılımcılarının işletmenin hukuki yapısı değiş̧kenine göre Independent-Samples T Testi sonuçları gösterilmiştir.

Tablo 10. Mikro ve Küçük İşletme Katılımcılarının İşletmenin Hukuki Yapısı Değişkenine Göre Independent-Samples T Testi Sonuçları

\begin{tabular}{|c|c|c|c|c|c|c|}
\hline \multicolumn{2}{|c|}{ Değişken } & N & Ortalama & Standart Sapma & t & p \\
\hline \multirow{2}{*}{$\begin{array}{c}\text { Hukuki } \\
\text { Yapı }\end{array}$} & $\begin{array}{c}\text { Şahıs Şirketleri } \\
\text { Sermaye Şirketleri (Ser.Pay.Böl. } \\
\text { Komandit/Anonim Şirket/Limited } \\
\text { Şirket) }\end{array}$ & 120 & 4,1648 & 0,81781 & & \multirow{2}{*}{0,282} \\
\hline
\end{tabular}

Yapılan analizler sonucunda p değeri 0,791>0,05 olduğu için $\mathrm{H}_{4}$ hipotezi olan "Mikro ve küçük işletmelerin muhasebe mesleğine bakış açlarının hukuki yapı değişkenine göre farklılaşması istatistiksel olarak anlamlıdır" ifadesi red edilmiştir. Dolayısıyla mikro ve küçük işletmelerin muhasebe mesleğine karşı tutumları işletmenin hukuki yapısı değişkenine göre farklılık göstermemektedir. Yani gruplar arasında oluşan farklılık istatistiksel açıdan anlamlı değildir.

Tablo 11'de mikro ve küçük işletme katılımcılarının işletmedeki çalışan sayısı değişkenine göre Independent-Samples T Testi sonuçları gösterilmiştir.

Tablo 11. Mikro ve Küçük İşletme Katılımcılarının İşletmedeki Çalışan Sayısı Değişkenine Göre Independent-Samples T Testi Sonuçları

\begin{tabular}{|c|c|c|c|c|c|c|}
\hline \multicolumn{2}{|c|}{ Değişken } & N & Ortalama & Standart Sapma & t & p \\
\hline $\begin{array}{c}\text { İşletmedeki } \\
\text { Çalışan Sayısı }\end{array}$ & Mikro İşletme(1-9 Kişi) & 239 & 4,1841 & 0,83992 & \multirow{2}{*}{0,448} & \multirow{2}{*}{0,735} \\
\cline { 2 - 6 } & Küçük İşletme(10-49 Kişi) & 63 & 4,1429 & 0,93078 & & \\
\hline
\end{tabular}


Yapılan analizler sonucunda p değeri 0,735>0,05 olduğu için $\mathrm{H}_{5}$ hipotezi olan "Mikro ve küçük işletmelerin muhasebe mesleğine bakış açılarının işletmedeki çalışan sayısı değişkenine göre farklılaşması istatistiksel olarak anlamlıdır" ifadesi red edilmiştir. Dolaysıyla mikro ve küçük işletmelerin muhasebe mesleğine karşı tutumları işletmedeki çalışan sayısı değişkenine göre farklılık göstermemektedir. Yani gruplar arasında oluşan farklılık istatistiksel açıdan anlamlı değildir.

Tablo 12'de mikro ve küçük işletme katılımcılarının işletmenin faaliyette bulunduğu sektör değişkenine göre One Way Anova testi sonuçları gösterilmiştir.

Tablo 12. Mikro ve Küçük İşletme Katılımcılarının İşletmenin Faaliyette Bulunduğu Sektör Değişkenine Göre One Way Anova Testi Sonuçları

\begin{tabular}{|c|c|c|c|c|c|c|c|c|}
\hline \multicolumn{2}{|c|}{ Değişken } & $\mathbf{N}$ & Mean & Standart & Kareler & Kareler & $F$ & $\mathbf{P}$ \\
\hline \multirow{4}{*}{$\begin{array}{c}\text { İşletmenin } \\
\text { Faaliyette } \\
\text { Bulunduğu } \\
\text { Sektör }\end{array}$} & Gida & 55 & 4,0727 & 0,87886 & \multirow{4}{*}{0,969} & \multirow{4}{*}{0,323} & \multirow{4}{*}{0,436} & \multirow{4}{*}{0,727} \\
\hline & Hizmet & 85 & 4,1882 & 0,98191 & & & & \\
\hline & $\begin{array}{c}\text { Otomotiv ve } \\
\text { Makina }\end{array}$ & 20 & 4,1000 & 0,64072 & & & & \\
\hline & Tekstil & 142 & 4,2183 & 0,79997 & & & & \\
\hline
\end{tabular}

Yapılan analiz sonucunda $p$ değeri $0,727>0,05$ olduğu için $\mathrm{H}_{6}$ hipotezi olan “Mikro ve küçük işletmelerin muhasebe mesleğine bakış açılarının işletmenin faaliyette bulunduğu sektör değişkenine göre farklılaşması istatistiksel olarak anlamlıdır" ifadesi reddedilmiştir. Dolayısıyla mikro ve küçük işletmelerin muhasebe mesleğine karşı tutumları işletmenin faaliyette bulunduğu sektör değişkenine göre farklılık göstermemektedir. Yani gruplar arasında oluşan farklılık istatistiksel açıdan anlamlı değildir.

Tablo 13' de mikro ve küçük işletme katılımcılarının muhasebe mesleğini yararlı bulunması değişkenine göre Independent-Samples T Testi sonuçları gösterilmiştir.

Tablo 13. Mikro ve Küçük İşletme Katılımcılarının Muhasebe Mesleğini Yararlı Bulunması Değişkenine Göre Independent-Samples T Testi Sonuçları

\begin{tabular}{|c|c|c|c|c|c|c|}
\hline \multicolumn{2}{|c|}{ Değişken } & N & Ortalama & Standart Sapma & t & p \\
\hline $\begin{array}{c}\text { Muhasebe mesleğini } \\
\text { yararlı buluyor musunuz? }\end{array}$ & Evet & 293 & 4,2184 & 0,79386 & \multirow{2}{*}{0,000} & 0,000 \\
\cline { 2 - 6 } & Hayır & 9 & 2,7778 & 1,56347 & & \\
\hline
\end{tabular}

Yapılan analizler sonucunda p değeri olan 0,000<0,05 olduğu için H7 hipotezi olan "Mikro ve küçük işletmelerin muhasebe mesleğine bakış açılarının muhasebe mesleğini yararlı bulunması değişkenine göre farklılaşması istatistiksel olarak anlamlıdır" ifadesi kabul edilmiştir. Dolayısıyla mikro ve küçük işletme katılımcılarının muhasebe mesleğine karşı tutumları, muhasebe mesleğini yararlı bulunması değişkenine göre farklılık göstermektedir. Yani gruplar arasında oluşan farklılık istatistiksel olarak anlamlıdır. 
Tablo 14. Mikro ve Küçük İşletme Katılımcılarının Muhasebenin Ürettiği Bilgileri İşletmeniz Açısından Faydalı Bulunması Değişkenine Göre One Way Anova Testi Sonuçları

\begin{tabular}{|c|c|c|c|c|c|c|c|c|}
\hline \multicolumn{2}{|c|}{ Değişken } & N & Mean & $\begin{array}{c}\text { Standart } \\
\text { Sapma }\end{array}$ & $\begin{array}{c}\text { Kareler } \\
\text { Toplamı }\end{array}$ & $\begin{array}{c}\text { Kareler } \\
\text { Ortalaması }\end{array}$ & F & P \\
\hline $\begin{array}{c}\text { Muhasebenin } \\
\text { ürettiği bilgileri } \\
\text { işletmeniz } \\
\text { açısından faydalı } \\
\text { buluyor } \\
\text { musunuz? }\end{array}$ & Evet & 241 & 4,2490 & 0,80897 & & & & \\
\cline { 2 - 8 } & Kayır & 13 & 3,4615 & 1,45002 & 9,406 & 4,703 & 6,624 & 0,002 \\
\hline
\end{tabular}

Tablo 14'te mikro ve küçük işletme katılımcılarının muhasebenin ürettiği bilgileri işletmeniz açısından faydalı bulunması değişkenine göre One Way Anova testi sonuçları gösterilmiştir. Yapılan analiz sonucunda p değeri 0,002<0,05 olduğu için H8 hipotezi olan "Mikro ve küçük işletmelerin muhasebe mesleğine bakış açılarının muhasebe muhasebenin ürettiği bilgilerin işletme açısından faydalı bulunması değişkenine göre farklılaşması istatistiksel olarak anlamlıdır" ifadesi kabul edilmiştir. Dolayısıyla mikro ve küçük işletme katılımcılarının muhasebe mesleğine karşı tutumları, muhasebenin ürettiği bilgileri işletmeniz açısından faydalı bulunması değişkenine göre farklılık göstermektedir. Yani gruplar arasında oluşan farklılık istatistiksel açıdan anlamlıdır.

Anova testinde hangi gruplar arasında farklılığın olup olmadığı Post Hoc testleri ile araştırılmaktadır. Eğer varyanslar homojen değil ise ve aynı zamanda örneklem sayıları da birbirine eşit değil ise Tamhan's T2 kullanılabilmektedir (Kayri, 2009: 56). Bu durumda tablo 14 'ün varyansları normal dağılmadığ $\breve{l}_{(\mathrm{P}=0,000<0,05)}$ ve örneklem sayıları da birbirine eşit olmadığı için Post Hoc testlerinden Tamhan's T2 kullanılmış ve elde edilen analiz sonuçları Tablo 15 'te gösterilmiştir.

Tablo 15. H8 Post Hoc Testi

\begin{tabular}{|c|c|c|c|c|}
\hline \multirow{7}{*}{$\begin{array}{c}\text { Muhasebenin ürettiği } \\
\text { bilgileri işletmeniz } \\
\text { açısından faydalı buluyor } \\
\text { musunuz? }\end{array}$} & \multicolumn{2}{|c|}{ Varyans Kaynağı } & Ortalamaların Farkı & $\mathbf{P}$ \\
\hline & \multirow{2}{*}{ Evet } & Hayır & 0,78742 & 0,209 \\
\hline & & Kismen & 0,24896 & 0,151 \\
\hline & \multirow{2}{*}{ Hayır } & Evet & $-0,78742$ & 0,209 \\
\hline & & Kismen & $-0,53846$ & 0,523 \\
\hline & \multirow{2}{*}{ Kismen } & Evet & $-0,24896$ & 0,151 \\
\hline & & Hayır & 0,53846 & 0,523 \\
\hline
\end{tabular}

Analiz sonucuna göre modelde bir bütün olarak gruplar arasında bir farklılık ortaya çıkmasına rağmen ikili testler sonucunda, gruplar arasında fark ortaya çıkmamıştır. Yani ikili gruplarda fark anlamlı değildir.

Yapılan analizlerin sonuçlarına göre hipotezlerin kabul/red durumu aşağıdaki tablo $16^{\prime}$ da özetlendiği gibidir. 
Tablo 16. Analiz Sonuçlarına göre Hipotezlerin Kabul / Red Durumu

\begin{tabular}{|c|c|}
\hline Hipotezler & $\begin{array}{c}\text { Kabul / Red } \\
\text { Durumu }\end{array}$ \\
\hline $\begin{array}{l}\text { H1: Mikro ve küçük işletmelerin muhasebe mesleğine bakış açılarının cinsiyet değişkenine göre } \\
\text { farklılaşması istatistiksel olarak anlamlıdır. }\end{array}$ & RED \\
\hline $\begin{array}{l}\text { Hz: Mikro ve küçük işletmelerin muhasebe mesleğine bakış açılarının işletmedeki pozisyonu } \\
\text { değişkenine göre farklılaşması istatistiksel olarak anlamlıdır. }\end{array}$ & KABUL \\
\hline $\begin{array}{l}\text { H3: Mikro ve küçük işletmelerin muhasebe mesleğine bakış açlarının eğitim durumu değişkenine } \\
\text { göre farklılaşması istatistiksel olarak anlamlıdır. }\end{array}$ & RED \\
\hline $\begin{array}{l}\text { H4: Mikro ve küçük işletmelerin muhasebe mesleğine bakış açılarının işletmenin hukuki yapısı } \\
\text { değişkenine göre farklılaşması istatistiksel olarak anlamlıdır. }\end{array}$ & RED \\
\hline $\begin{array}{l}\text { H5: Mikro ve küçük işletmelerin muhasebe mesleğine bakış açılarının işletmedeki çalışan sayısı } \\
\text { değişkenine göre farklılaşması istatistiksel olarak anlamlıdır. }\end{array}$ & RED \\
\hline $\begin{array}{l}\text { H6: Mikro ve küçük işletmelerin muhasebe mesleğine bakış açılarının işletmenin faaliyette } \\
\text { bulunduğu sektör değişkenine göre farklılaşması istatistiksel olarak anlamlıdır. }\end{array}$ & RED \\
\hline $\begin{array}{l}\text { H7: Mikro ve küçük işletmelerin muhasebe mesleğine bakış açlarının muhasebe mesleğinin } \\
\text { yararlı bulunması değişkenine göre farklılaşması istatistiksel olarak anlamlıdır. }\end{array}$ & KABUL \\
\hline $\begin{array}{l}\text { H8: Mikro ve küçük işletmelerin muhasebe mesleğine bakış açılarının muhasebenin ürettiği } \\
\text { bilgilerin işletme açısından faydalı bulunması değişkenine göre farklılaşması istatistiksel olarak } \\
\text { anlamlıdır. }\end{array}$ & KABUL \\
\hline
\end{tabular}

Yukarıdaki Tablo 16' da da görüleceği üzere analizde kullanılan hipotezlerden 3 hipotez $\left(\mathbf{H}_{2}\right.$, $\mathbf{H}_{7}$ ve $\left.\mathbf{H}_{8}\right)$ kabul edilmiş, 5 hipotez ise $\left(\mathbf{H}_{1}, \mathbf{H}_{3}, \mathbf{H}_{4}, \mathbf{H}_{5}\right.$ ve $\left.\mathbf{H}_{6}\right)$ reddedilmiştir.

\section{SONUÇ}

Muhasebe mesleği, işletmenin alacağı kararlarda yol gösterici nitelik taşıyan ekonomik hayatta giderek artan öneme sahip olan bir meslek olması ve işletme açısından muhasebenin ürettiği bilgilerin işletme yöneticilerinin kararlarından çalışanların kararlarına kadar tüm bireyler için önemli olması söz konusudur. Dolayısıyla mikro ve küçük işletmelerin muhasebe mesleğine bakış açıları farklılık göstermekte ve bu farklılığın tespit edilmesine yönelik bir araştırma yapılmıştır.

$\mathrm{Bu}$ doğrultuda araştırmada Isparta ilinde faaliyet gösteren mikro ve küçük işletmelerin muhasebe mesleğine karşı tutumlarının tanımlayıcı değişkenlere göre farklılaşıp farklılaşmadığı araştırılmıştır. Araştırmanın evrenini Isparta ilinde faaliyet gösteren mikro ve küçük işletmeler oluşturmaktadır. 302 kişinin katılım sağladığ 1 araştırmada kadın katılımcların sayısı 135, erkek katılımcıların sayısı 167 kişiden oluşmaktadır. Anket veri toplama tekniği ile 302 katılımcıdan yüz yüze görüşme yöntemi ile veriler elde edilmiştir. Anket formu iki bölümden oluşmaktadır. Birinci bölüm katılımcıları tanımaya yönelik 11 tanımlayıcı sorulardan oluşmakta, ikinci bölüm ise 5'li likert ölçeğe göre hazırlanmış olan muhasebe mesleği ile ilgili ifadelerden oluşmaktadır.

Araştırmanın amacına yönelik elde edilen verilerde Cronbach's Alpha aralığg belirlenmiştir. Tanımlayıcı sorularının frekans ve yüzde dağılımları gösterilmiş ve hipotez testleri gerçekleştirilmiştir. Araştırmada 8 tane hipotez kurulmuştur. Hipotezlere IndependentSamples T Testi ve One Way Anova testi analizleri uygulanmıştır. Bu hipotezlerden 3'ü kabul edilmiş, 5'i reddedilmiştir. Araştırmanın sonucunda işletmedeki pozisyonunuz değişkeni, muhasebe mesleğinin yararlı bulunması değişkeni ve muhasebenin ürettiği bilgilerin işletme 
açısından faydalı bulunması değişkeni hipotezlerinin kabul edildiği ve mikro ve küçük işletmelerin muhasebe mesleğine bakış açılarının bu değişkenlere göre istatistiksel açıdan anlamlı bir farklılık olduğu sonucuna ulaşılmıştır. Mikro ve küçük işletme temsilcilerinin muhasebe mesleğine karşı tutumlarının diğer tanımlayıcı değişkenler üzerinde etkisinin olmadığı ortaya çıkmıştır.

Araştırmada, Isparta ilinde faaliyet gösteren mikro ve küçük işletme temsilcilerinin muhasebe mesleğinin; bilgi ve birikim gerektiren bir meslek olduğu $(\% 90,4)$, aktif bir meslek olduğu $(\% 88,1)$, toplum tarafından kabul gören bir meslek olduğu $(\% 82,5)$, sorumluluk almayı gerektiren bir meslek olduğu (\%87,7), yüksek gelir getiren bir meslek olduğu (\%54,3), işletme bilgilerinin gizliliği konusunda dikkatli olunmasını gerektiren bir meslek olduğu $(\% 86,1)$, ticari işlemlerin yanında aynı zamanda kurumsal danışmanlık yapmayı gerektiren bir meslek olduğu $(\% 71,2)$, mükellef-kamu çıar dengesini eşit şekilde koruyan bir meslek olduğu $(\% 71,5)$, mali nitelikteki işlemlerin usulüne uygun şekilde yapılmasını gerektiren bir meslek olduğu $(73,2)$, yeniliklere açık ve kolay uyum sağlamasını bilen bir meslek olduğu $(\% 70,9)$, kariyer yapma firsatı olan bir meslek olduğu (\%52,3), güncelliğini her zaman koruyan bir meslek olduğu $(\% 79,1)$ ve genel anlamda gizlilik gerektiren bir meslek olduğu $(\% 84,4)$ tutum ve düşüncede oldukları sonucuna ulaşılmıştır.

Literatür taraması yapıldığında muhasebe mesleğine bakış açılarının tespit edildiği çalışmalar ortaya çıkmaktadır. Genel olarak bu çalışmalar konu ve amaç bağlamında, muhasebe dersi alan ve almayan öğrencilerin görüşleri ve muhasebe meslek mensuplarının muhasebe mesleği hakkındaki görüşlerine yönelik çalışmalardır. Fakat literatürde KOBİ'lere yönelik muhasebe mesleği hakkındaki görüşlerinin ve muhasebe mesleğine karşı tutumlarının tanımlayıcı değişkenlere göre farklılıklarının olup olmadığının araştırıldığı herhangi bir çalışma tespit edilememiştir. Bu nedenle bu çalışma gerçekleştirilmiştir. Bundan sonraki araştırmalarda da araştırmacılar farklı illerdeki mikro ve küçük işletme katılımcılarına yönelik benzer araştırmalar yapılabileceği gibi orta ve büyük işletme katılımcılarına yönelik de bir araştırma yapılabileceği ve bu araştırma sonuçları ile karşılaştırılarak ortaya çıkan farklılık ve benzerliklerin nedenlerini ortaya koyan bir araştırma yapılması mümkündür.

\section{KAYNAKÇA}

Akdoğan, H. (2003). Muhasebe Meslek Etiğinin Kamunun Aydınlatılmasındaki Önemine Meslek Mensuplarının Yaklaşımları. Yayınlanmamış Doktora Tezi, Anadolu Üniversitesi Sosyal Bilimler Enstitüsü, Eskişehir.

Aksoylu, S., Boztosun, D., Baraz, E. H., ve Altınışık, F. (2018). Muhasebe ve Finans Eğitimi Alan Öğrencilerin Muhasebe Mesleğine Bakış Açları. Business and Organization Research, 648-659.

Albez, A. ve Bilici, N. (2012). Meslek Yüksekokulları Muhasebe Öğrencilerinin Mesleğe Bakışları: Atatürk Üniversitesi'nde Bir Araştırma. Atatürk Üniversitesi Sosyal Bilimler Enstitüsü Dergisi, 16(3), 383-398.

Aydın, Y. (2018). Üniversitelerde Verilen Muhasebe Eğitiminin Sivas İlinde Faaliyet Gösteren Küçük ve Orta Büyüklükteki İşletmeler ve Serbest Muhasebeci Mali Müşavirlerin Beklentilerini Karşılama Düzeyinin İncelenmesi. Cumhuriyet Üniversitesi İktisadi ve İdari Bilimler Dergisi, 19(1), 1-23. 
Bekci, İ. ve Usul, H. (2001). Göller Bölgesindeki Küçük ve Orta Boy İşletmelerin Finansal Sorunları ve Çözüm Yolları. Süleyman Demirel Üniversitesi İ̈BF Dergisi, 6(1), 111-125.

Civelek, M. A. ve Durukan, M. B. (1997). Günümüz Koşullarında Muhasebe Mesleği ve Meslek Ahlakı. Uluslararası Muhasebe Sempozyumu, III. Türkiye Muhasebe Denetimi Sempozyumu, Muhasebe Denetimi Mesleğinde Yetkiler, Sorumluluklar ve Meslek Ahlakı, ISMMMO Yayınları, No:20, (3), 1-10.

Demir, Ö. ve Tanyıldızı, İ. (2017). Muhasebe Kültüründe Etik Değerlerin Etkisinin Chaid Analizi İle İncelenmesi: Elazığ İlinde Yapılan Bir Araştırma. Fırat Üniversitesi Sosyal Bilimler Dergisi, 27(2), 193-214.

Ekşi, İ.H., Özçalıcı, M. ve Büyükkoyunlu, B. (2011). Meslek Algılanmasında Etkili Olan Faktörler: Muhasebecilik Örneği. Muhasebe ve Finansman Dergisi, Ekim, (52), 67-80.

Erduru, İ., Deran, A. ve Çelik, S. (2017). Muhasebe Eğitimi Alan Öğrencilerin Muhasebe Mesleğine Bakış Açılarının İncelenmesi: Ömer Halis Demir Üniversitesi Örneği. İşletme ve İktisat Araştırmaları Dergisi, 5(2), 34-48.

Kalaycı, Ş. (2009). SPSS Uygulamalı Çok Değişkenli İstatistik Teknikleri. Ankara: Asil Yayın Dağıtım.

Kayri, M. (2009). Araştırmalarda Gruplar Arası Farkın Belirlenmesine Yönelik Çoklu Karşılaştırma (Post Hoc) Testleri, Fırat Üniversitesi Sosyal Bilimler Dergisi, 19(1), 5164.

Tepeli, Y. Ve Kayıhan, B. (2015). Muhasebe Eğitimi Alan Öğrencilerin Muhasebe Mesleğine Bakış Açılarının Değerlendirilmesi: Muğla Sıtkı Koçman Üniversitesi Örneği. Yönetim ve Ekonomi Araştırmaları Dergisi, 13(3), 138-156.

Yüreklï, E. (2017). Pamukkale Üniversitesi Honaz Meslek Yüksekokulu Öğrencilerinin Muhasebe Eğitimine ve Mesleğe Bakış Açılarının Araştırılması. Muhasebe Bilim Dünyası Dergisi, 19(1), 319-339.

http://www.kosgeb.gov.tr/, (Erişim: 03.03.2020).

http://www.mfa.gov.tr/, (Erişim: 04.03.2020).

3568 Sayılı Serbest Muhasebeci Mali Müşavirlik ve Yeminli Mali Müşavirlik Kanunu. URL: http://www.ismmmo.org.tr/, (Erişim: 27.03.2020).

Küçük ve Orta Büyüklükteki İşletmelerin Tanımı, Nitelikleri ve Sınıflandırılması Hakkında Yönetmelik. URL: http://www.kosgeb.gov.tr/ , (Erişim: 03.03.2020). 